\title{
悪性高熱と思われた一症例
}

\author{
田中 幸穂・高須賀信夫・堤 昭一郎*・吉見 誠一**
}

\section{A Case Report of Possible Malignant Hyperthermia}

\author{
Yukio Tanaka, Nobuo Takasuka, Shyoichiro Tsutsumi \\ and Seiichi Yoshimi
}

(Ehime Central Hospital)

\begin{abstract}
A 30-year-old man was anesthetized with GOE (E: Enflurane) slow induction and SCC was given intravenously for intubation. When the anesthesiologist tried oral intubation he noticed rigidity of the masseter muscle and discontinued the anesthetic agents immediately. Two hours after recovery from anesthesia we found port-wine-colored urine. Myoglobine of both serum and urine were 25,000 and 960,000 ng/dl and serum GOT, LDH and GPK were $586 \mathrm{Ku} .2499 \mathrm{Wu}$. and 106,000 Iu., respectively. All the data returned to nearly normal values within seven days. Perspiration was noted though there had been only slight fever $\left(37^{\circ} \mathrm{C}\right)$ for several days. Systemic circulation did not show any significant changes throughout the course without slight tachycardia.

Diuretics and intravenous transfusion of about $5,000 \mathrm{ml} /$ day were given to maintain a recommended urine output of $200 \mathrm{ml} /$ hour in order to preserve renal function.

For prevention of malignant hyperthermia past history, family anamnesis and preoperation test must be examined, however at present prediction is not always possible on the basis of these data. If one suspects malignant hyperthermia, the best therapy is the following: (1) discontinuation of anesthetic agents, (2) rapid and effective cooling, (3) avoidance of hypoxia and (4) treatment of developing acidosis. One should obtain expert evaluation from an anesthesiologist.
\end{abstract}

はじめに

全身麻酔によって起てる重篤な合併症の一つに1964年 Saidman ら" が報告して以来注目される ようになった曹性高熱 (症)（malignant hyperthermia）があげられる. 症状の出現は既往歴, 家 族歴, 術前検查等で予知困難であり，術中あるいは術後然然に発症し，死亡率 $50 \%$ 以上高く数時 間以内に死亡するものあある. 耳鼻科医がこうした症例に遭遇することは稀で無縁に思われがちで あったが，わが国でも最近かなりの症例が報告されており，救命しえたと思われる症例を知識不足 の為致死に至らしめることが十分に起てりうる。そこで今回我々が経験した悪性高熱と思われた症 例を中心に若干の知見を加えて報告する。

* 愛媛県立中央病院耳鼻科

** " 麻酔科 
症

表 I 術前検査值

30 y.o. man $163 \mathrm{~cm} 59 \mathrm{~kg}$

RBC $489 \times 10^{4}$

$\mathrm{Hb} \quad 15.4 \mathrm{~g} / \mathrm{dl}$

$\mathrm{Ht} \quad 44.5 \%$

WBC 7100

GOT $\quad 17 \mathrm{ku}$

GPT $\quad 44 \mathrm{Ku}$

Al-p $\quad 6.5 \mathrm{KAu}$.

T-Bil. $\quad 0.7 \mathrm{mg} / \mathrm{dl}$

LDH $432 \mathrm{wu}$

Prot. $\quad 7.5 \mathrm{~g} / \mathrm{dl}$

$\mathrm{Na} \quad 143 \mathrm{mEq} / \mathrm{l}$

$\mathrm{K} \quad 3.8$

Cl 99

Urine

Protein (-)

Glucose (-)
Chest X-P:n.p

$E C G: W N L$

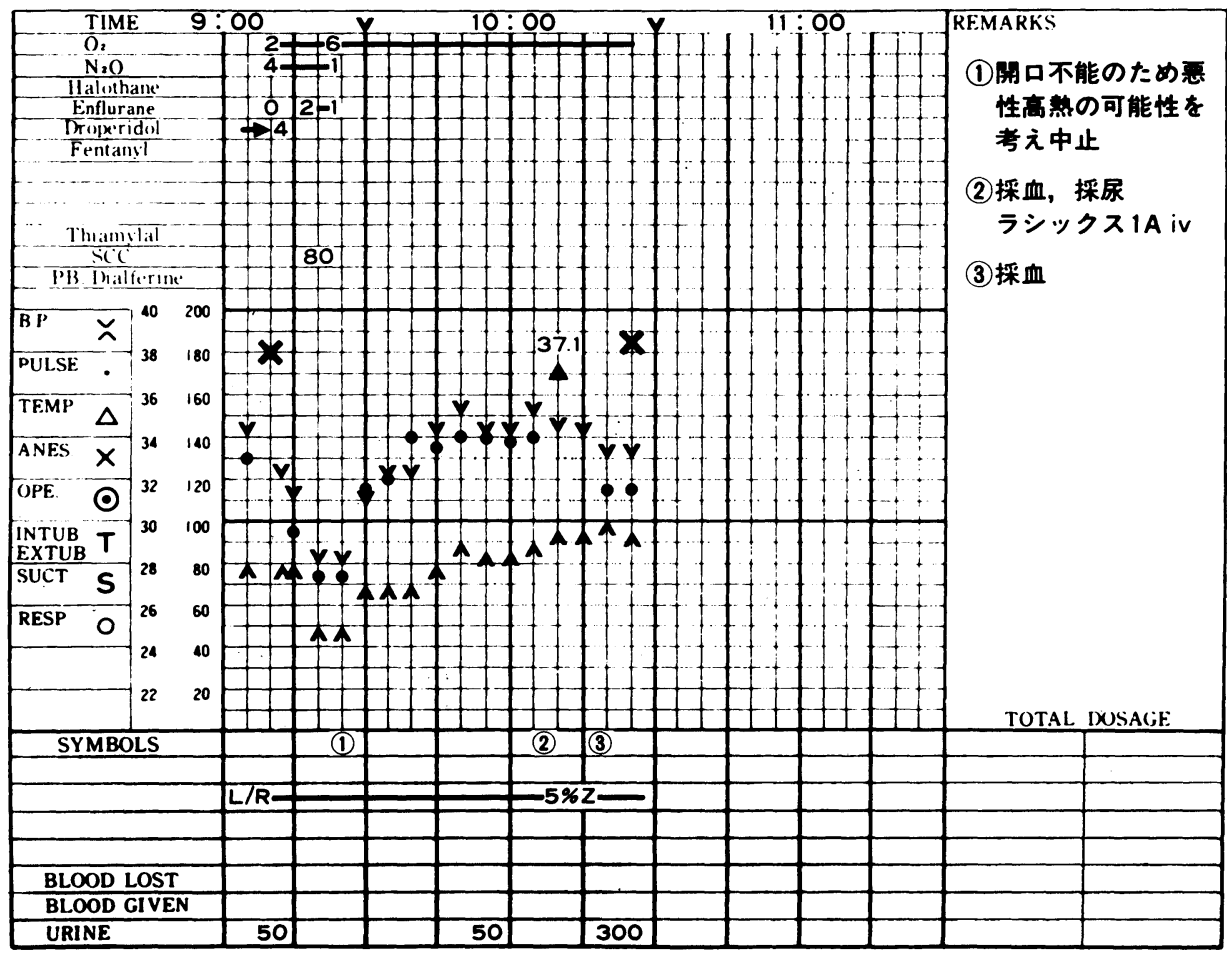

図1麻酔記録

患者は30才の男性でメニエル氏病の診断にて 全身麻酔下に内リンパのう開放術を行う予定で あった。術前検査值を表 1 に示したが，L D H のごく軽度の上昇以外異常を認めなかった。

前投薬にはアトロピン $0.5 \mathrm{mg}$ ，デキサメサゾ ン $5 \mathrm{mg}$ を筋注し手術室に搬入した。

林酔は GOE（G：笑気， $\mathrm{O}$ ：酸素， $\mathrm{E} ： 工$ ンフルレン) の slow induction にて導入し,

S C C (succinylcholine chloride) 80mg静注: 後気管内插管学試みる屯, 咬筋のrigidity が強 く開い|障管著明にて墨性高熱を疑い手術を延 期，麻酔は即時中止し覚醒させた。約 1 時間乎 術室で経過観察を行なったが，体温，循環動 態，尿に著変がみられなかったので州室させ た。麻配経過を図 1 に示した。帰室後 1 時間半 よりポートワイン色の血尿が出現してきたので 治療を開始した。 
林酔後の体温と心拍数を図 2 に示した。体温 は 5 日間平均 $37^{\circ} \mathrm{C}$ と軽度の上昇に過ぎなかった が, 発汗は数日間非常に著明であり，1日に数 回寝具の交換を必要とした。しかし体温に関し ては積極的な治療を必要としなかった。 心拍数 は約100回/分が持続し, 麻酔後 5 日目に体温 の下降がみられると共に80回/分前後に減少し た．血压はほとんど変化がみられず，不整脈む 全経過中認められなかった。

GOTは当日 $586 \mathrm{Ku}$. と高值を示したが徐々

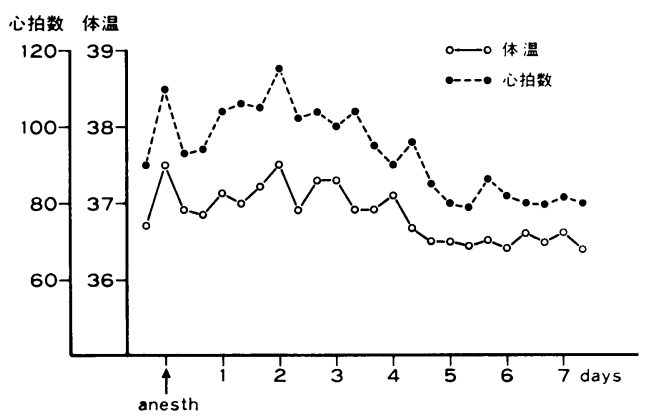

図 2 麻酔後の体温と心拍数

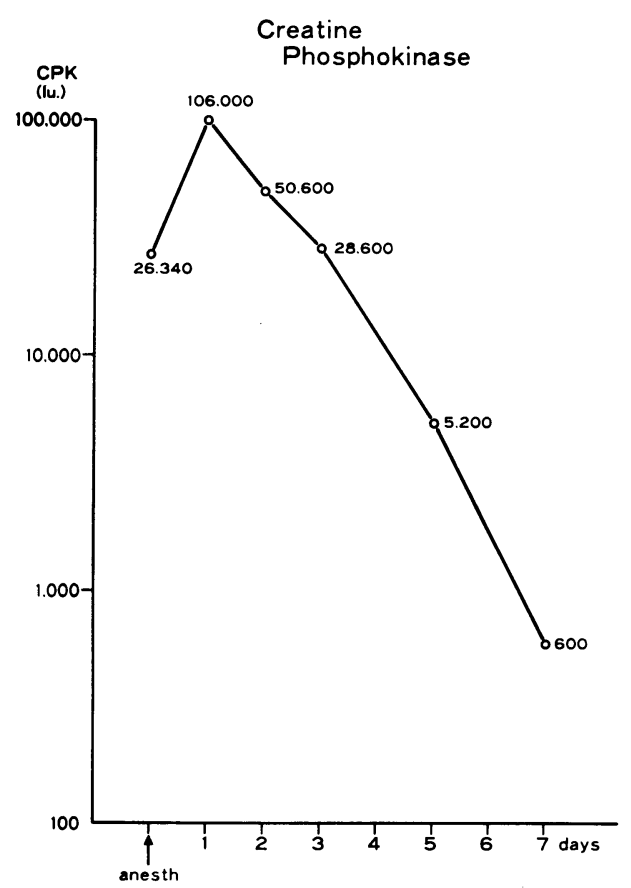

図 4 術後の C P K 值. 縦軸は対数表示した.

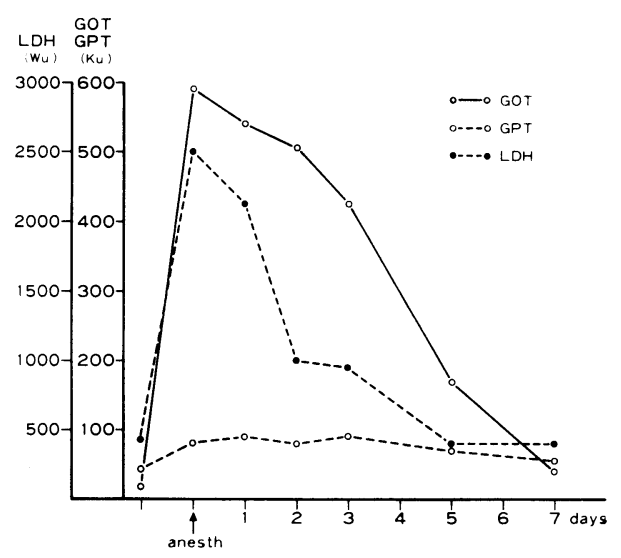

図 3 麻酔後のG OT, G P T および L D H

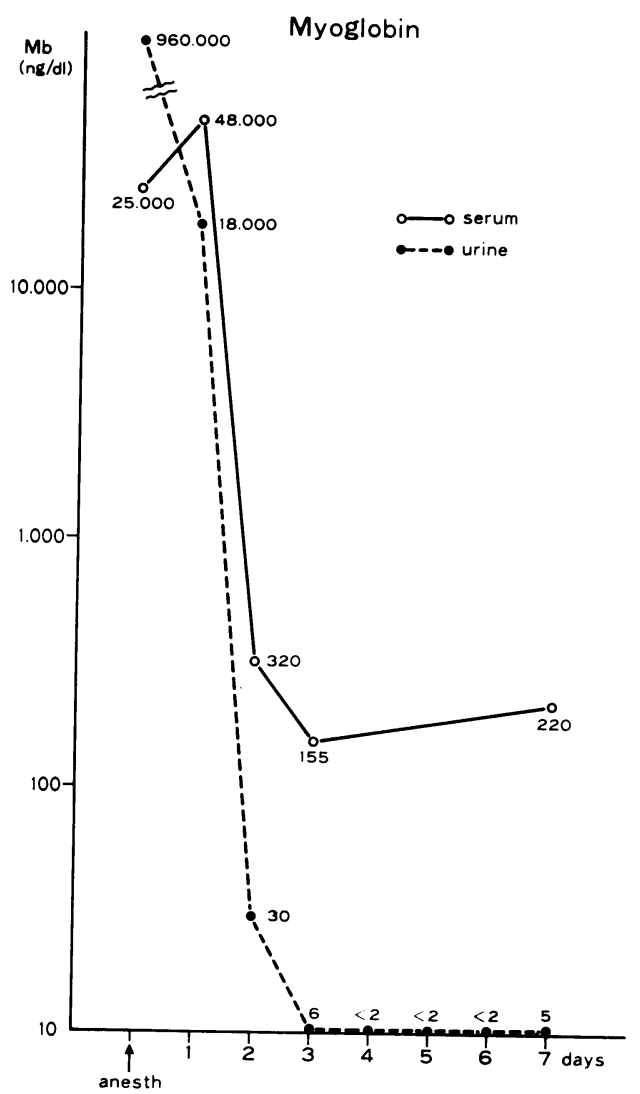

図 5 血清中および尿中のミオグロビン值. 縦軸は対数表示した。 
にト降し， 1 週間後には $41 \mathrm{Ku}$. と心: 常值に低 下した，GPTは $80 \mathrm{Ku}$. とごく訤度の上昇がみ られただけであった，L D Hは当日 $2499 W u$. とト䈙したが 5 日目には $386 \mathrm{Wu}$. と洁常值に復 した（図 3 )。四 4 はC P K を示し，横軜に日 数，縦軸は対数表ホした。当日 $26,340 \mathrm{Iu}$. であ り㽜日には106, 000Iu. という異常高值を示した が，徐々に下降し 7 日目600Iu.になった。それ 以後は測定しなかったので何日目に正常値に戻 ったかは不明である。尿は恘酔当日はワインレ ッドであり翌日には肉眼的に黄色となったが， 潜烅反心は 5 月目まで続き 6 日目にやっと(けと なった。

四 5 に血清中及び㽷中のミオグロビン偵を示 した. 図 4 同様縦軸は対数表示した.ミオグロビ

令回の症例は朋機能検 查で L D H が $432 W u$ （i上: 常值50４00）とごく軽度の上昇以外は， 血液，尿検査で異常がなかった。麻徆浆も導入 時15分間吸入させたのみでポートワイン尿の出 現, 血清及び尿中のミオグロビン值の異常高值 とGOT，LDH，C P K の著明な上昇を認め た。しかし異常発熱はみられなかった。一体致 死率の高い覀性高熱とはどのようなものであろ うか。本症の原因，診断，治療等について盛 生 $^{2)}$ ，篠原ら ${ }^{3)}$ の報告を参考に検討を行なって みた。

用棓としては Malignant hyperthermia, Malignant hyperpyrexia が用いられ，日本珗 学会では悪性高熱（症）または悪性高体温とし ている，発生率は報告により異なるが Britt によ机ば小児は $1 / 15,000$ 人，成人では $1 / 50,000$ 人とし，死亡率は約 $64 \%$ ああり， $40^{\circ} \mathrm{C}$ 越えな かった症例は $10 \%$ ，反対に $42^{\circ} \mathrm{C}$ 以上発熱した場 合は $82 \%$ に達している5

墨性高熱は麻酔诌，麻酔補助楽求よびその他 の刺激によって(1)筋強直之発熱をきたすもの,

(2)あきらかな筋強值、を認めないが，高熱を発す るもの，(3)筋強直上ミオグロビン尿を認める
ンは radioimmunoassay 2 抗体法にて測定し た. 但清ミオグロビン值は当日 $25,000 \mathrm{ng} / \mathrm{dl}$, 翌 日 $48,000 \mathrm{ng} / \mathrm{dl}$ と上昇したが 2 日目より急激に 減少した。尿中ミオグロビン值は当日 960,000 $\mathrm{ng} / \mathrm{dl}$ という高值を示し, 以後 $18,000 \mathrm{ng} / \mathrm{dl}$ と なり4日目には泟常值になった。

森酔後命併症としての婜不全を防止する為に 尿量は $200 \mathrm{ml} /$ 侍間を目慓にし，生理食塩水対 5 \%糖を 2 対 1 の割で約 $5,000 \mathrm{ml} /$ 日の輸液療法 と利尿楽を使用した。乙の間適宜電解質を測定 し補正を行なった。潜价反㣽(ととなた 6 日 目より輸液量を減少させていったが腎機能障害 は発症せず，他の合併症も生じなかった。後日 局所麻酔で手術を無事完了し，患者は現在めま い屯無く元気に生活している.

察

が，発熱は軽度のもの，(4)觔強直はあきらかで ないが，中等度の発熱をきたすむのとし，(1)を rigidity type, (2)を non-rigidity type に分 類し ${ }^{6)} ，(3) ，(4)$ は曲型ではないかと考えられて いる.

診断基準としては盛生 ${ }^{2)}$ によれば(1)15分間 に0. $5^{\circ} \mathrm{C}$ 以上または 1 時間に $2{ }^{\circ} \mathrm{C}$ 以上の体温の 上昇するもの，(2)筋強古を認め尿中にミオグロ ビンを綛めるもの，(3)原因不明の頻脈と不整脈 の発症，(4)血液ガス分析によってアシドーシス を認めた場合，(5)L D H， G O T, C PK， ミオグロビンが術後 $1 \sim 2$ 週間以上にわたって 漸減する屯の，(6)合併症としてミオグロビン, へモグロビンによる尿紐管の閉寒が急性腎不全 をむたらし，溶血の為出血傾向がみられる等あ らゆる合併症が考えられる。

病態については $\mathrm{Britt}^{7}$ は吸入麻酔楽が筋小 胞体の膜に変化を起こして $\mathrm{Ca}^{+}$を遊離し，乙 の結果, 筋強直加ら筋㹬直へと移行するため発 熱を生じる， S C C は脱分極を起こし $\mathrm{Ca}^{+}$の 遊離を促進させる役割を演じているが，筋小胞 体の膜には特別な役割を演じていないと述べて いる。 
全身麻酔とミオグロビンの関係については稲 垣ら ${ }^{8)}$ (麻酔経過上異常のみられなかった患者 ではGOF（F：ハロセン）麻酔のみの場合に は血中ミオグロビンの変動はみられないが S C Cを静注すると全例に血中ミオグロビンの上昇 が認められた。しかし d-tubocurare を投与. しておくとミオグロビンの上昇がみられないこ とから筋攣縮が関係していることは明らかであ ると報告している．

治療法としては現在のとてろ決め手がなく対 症療法しかないが，早期発見と早期治療が予後 の鍵となる。悪性高熱が疑われたら(1)麻酔を中 止し発熱のある時は早期より積極的な冷却を行 う, (2)吸入麻酔薬を N L A 等の静脈麻酔薬に変 更する，(3)純酸素による過呼吸を行う，(4)アシ ドーシスに対して重曹水の静脈内注入を行う, (5)腎障害の予防の為積極的に輸液と利尿薬を使 用し尿量を確保する，(6)頻脈や不整脈に対して はリドカインの使用は禁忌であるが, プロカイ ン，プロカインアミドを使用する.

我々の症例は検査上は悪性高熱と同様の所見 を示したにも拘らず，体温の上昇が軽度で大事 に至らなかったのは吸入麻酔薬，SＣＣが導入 に用いられたのみで，それ以後の投与を中止し たためと思われる。 あし麻酔を持続していたな
ら不幸な結果になったてとが十分予測されたと とを考慮すれば, 今回の我々の処置は最善の方 法であっただろうと自負している.

安全な麻酔法を行なうにはストレスを極力少

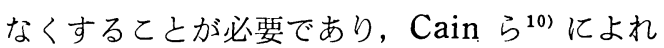
ば使用可能な麻酔薬としてサイオペントン, ア ルテシン, フェンタニール, ドロペリドール, ディアゼパム, 塩酸プロカインを, 使用不適当 な麻酔薬として揮発性吸入麻酔薬, 脱分極性筋 弛緩剂，リドカインを挙げている，新ステロイ ド系静脈麻酔剤（アルテシン）やダントロレン を豚に投与することによりハロセンや S C Cを 用いても悪性高熱は発症しなかったとする報告 あある ${ }^{1112)}$. 術前 C P K の異常が悪性高熱の発 症の予測に有用であるといわれているが，森川 $ら^{13)}$ は悪性高熱患者を同定する検査としては全 く役立たず，発生した家系での検査としては役 立つとしている。いずれにせよ覀性高熱の予測 は現在のとてろ全くできず，既往歴，家族歴， 術前検査は必要不可欠であるが発生を阻止する ことはできない。すし発症が疑われたら先に述 ベた治療法を行ない，即座に専門家に相談し適 切な指示を仰ぐことが現時点として最良の治療 法と思われる.

\section{ま と め}

全身麻酔により発症した悪性高熱と思われる症例を報告した.

1) G OEの slow induction で導入し気管内捚管の為 S C C を静注したとてろ咬筋の強直がみ られたので即時麻酔を中止した.

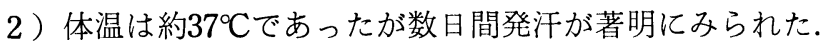

3 ）麻酔後よりポートワイン尿が出現し血清中及び尿中のミオグロビン值は $25,000 \mathrm{ng} / \mathrm{dl}$, 960,000ng/dl, GOT586Ku., LDH2499Wu., CPK106,000Iu. まで上昇した.

4 ) 循環動態は心拍数の軽度上昇が認められたが, 血圧等には変化がなかった.

5 ) 腎機能を維持する為に多量の輸液と利尿薬を使用した.

\section{参考文 献}

1) Saidman, L. J. et al : Hyperthermia during anesthesis. JAMA 190: 1029 1032, 1964.

2 ) 盛生倫夫 : 覀性高熱症. 麻酔 29 ：1～10, 1980,
3) 篠原祥三ほか：麻醉時悪性過高熱. 高知市民病院 紀要 $3: 1 \sim 14,1977$.

4) Britt, B. A. : Recent advances in malignant 
hyperthermia. Anesth. Analg. 51:841 850, 1972.

5) Wilson, R. D. et al : Malignant hyperpyrexia with anesthesia. JAMA $202: 183 \sim 186,1967$,

6) Britt, B. A. et al : Malignant hyperthermia : A statistical review. Canad. Anaesth. Soc. J. $17: 293 \sim 315,1970$.

7) Britt, B. A. and Kalow, W. : Malignant hyperthermia. Aetiology unknown. Canad. Anaesth. Soc. J. $17: 316 \sim 330,1970$.

8 ) 稲垣 稔ほか：GOF麻酔時サクシニルコリン投 与による血中ミオグロビン值の変動. 麻酔 29 : 1476〜1482, 1980.

9 ) Beldavs, J. et al : Postoperative malignant hyperthermia : a case report. Canad. Anaesth. Soc. J. $18: 202 \sim 212,1971$.
10) Cain, P. A. et al : Anaesthesis for patients susceptible to malignant hyperthermia. Brit. J. Anaesth. $49: 941 \sim 944,1977$.

11) Hall, L. W. et al : Further studies of Porcine malignant hyperthermia. Brit. Med. J. 2 : 145 148, 1972.

12) Gronert, G. A. et al: Dantrolen in porcine malignant hyperthermia. Anesthesiology 44 : 488〜 495, 1976.

13）森川定雄ほか：麻酔前 C P K 值之その異常につい て. 麻酔 $28: 187 \sim 196,1979$.

原稿到着：昭和57年 9 月 6 日 別刷請求先：田中幸穂 巴790 松山市春日町83番地 愛媛県立中央病院耳鼻咽喉科 